\title{
Preliminary in-vitro evaluation of marketed formulations for antacid activity
}

\author{
Pranjali P. Dhawal ${ }^{1}$, Siddhivinayak S. Barve ${ }^{2}$
}

\author{
${ }^{1}$ Department of Animal Biotechnology and Biochemistry, ${ }^{1,2}$ KET’s Scientific Research Centre, Mumbai, Maharashtra, \\ India
}

Received: 05 December 2019

Revised: 20 December 2019

Accepted: 21 December 2019

\section{*Correspondence:}

Mr. Pranjali P. Dhawal,

Email: animalbiotechnologysrc@gmail.com

Copyright: (C) the author(s), publisher and licensee Medip Academy. This is an open-access article distributed under the terms of the Creative Commons Attribution Non-Commercial License, which permits unrestricted non-commercial use, distribution, and reproduction in any medium, provided the original work is properly cited.

\begin{abstract}
Background: Hydrochloric acid ( $\mathrm{pH}$ 1.5-3.5) being the major component of gastric acid is produced by parietal cells of stomach. Its secretion is a complex and relatively energetically expensive process. The preservation of acidity of stomach is evidently important because of its implications in peptic and duodenal ulceration.

Methods: In the present study, we attempted to compare the activity of 13 (F1-F13) antacid formulations (5-liquid, 4quick releases and 4- tablets) by using acid-base neutralization studies. Preliminary antacid test (PAT) was performed to define whether the given formulation falls under the category of antacid wherein the $\mathrm{pH}$ of the antacid-acid $(\mathrm{HCl})$ solution should be higher than $\mathrm{pH}$ of 3.5. The chosen antacids were further subjected to acid neutralizing capacity (ANC) (reaction between the sample of antacid and amount of acid neutralized by the formulation) and acid neutralizing potential (ANP) which explains the time duration during which a given sample of antacid can maintain $\mathrm{pH}$ above 3.5).

Results: Out of the 13 samples tested, two formulations of pastels (F6, F12) were rejected as per the standard protocol of classifying formulations as antacids after screening for PAT. Sample F5 was found to have the highest ANC. F7 also showed highest ANC among the tablets tested. Also, F13 showed better ANC and ANP as in comparison to other quick releases.

Conclusions: Digene products (F5, F7, and F13) showed better antacid properties. This data would provide insights into development of drug, comparison between antacids depending on their chemical formulation and determination of dosage to avoid plausible side effects.
\end{abstract}

Keywords: Antacid, ANC, ANP, Peptic ulceration, PAT

\section{INTRODUCTION}

Three million times of $\mathrm{H}^{+}$ions compared to blood and tissues are produced by highly specialized cells of corpus of stomach called the parietal cells. This gastric acidity reflects biological importance because of its involvement in acid-related diseases. Acid secretion in stomach is controlled by endocrine cells, neurons, gastrin, histamine and acetylcholine however the way these cells and molecules interact to stimulate gastric acidity remains debated. ${ }^{1}$ Gastric mucosa is under attack by endogenous factors such as histamine, acid, pepsin, reflux bile, leukotrienes, pro-inflammatory cytokines, ischemia, activated neutrophils, reactive oxygen species, proapoptotic proteins and exogenous factors such as stress, non-steroidal anti-inflammatory drugs (NSAIDs) that can cause gastric damage and ulceration. ${ }^{2}$

A variety of pharmacological (anticholinergics, H2 blockers and proton pump) and non-pharmacological 
(gastric surgery) approaches have been proposed throughout history for inhibition of gastric secretion that can lead to ulceration. ${ }^{3}$ Peptic ulceration has traditionally been managed by antacid therapy which includes drugs that raise the $\mathrm{pH}$ of stomach contents by either of the two mechanisms: direct neutralization of acid and blocking acid production. ${ }^{4}$ Antacids are commonly used worldwide as over-the-counter (OTC) or prescribed medications for the treatment of acid-peptic disorders such as peptic ulcers, gastritis, gastro-oesophageal reflux disease (GERD) and functional dyspepsia. ${ }^{5}$

Primarily, antacids are alkaline substances that reduce gastric acidity by neutralization of hydrochloric acid in the stomach. Moreover, pharmacological properties have been defined such as $\mathrm{pH}$ interval of $3-5$, but no acid rebound provocation; fast onset of action; long-lasting efficacy; high neutralization potential and capacity. These are some of the factors necessary for the preparation of modern antacid formulations. This variability amongst antacids can be compared by analysing preliminary antacid test (PAT), acid neutralizing capacity (ANC) and acid neutralizing potential (ANP) efficiencies of the antacids. For PAT, if the antacid-acid solution shows $\mathrm{pH}$ above 5, the antacid may provoke acid rebound and result in adverse effects such as bloating, meteorism and eructation. $^{6}$

Since the significance of antacids is inevitable in the treatment of gastrointestinal problems, there is a need to understand the efficacy of the antacids available in markets. Also, over the years, many pharmaceutical companies have come up with many antacid formulations which can be divided as a liquid, tablets, pastel and quick releases. An attempt has been made through this research to compare the antacid formulations for different activities such as PAT, ANC and ANP. Table 1 mentions the type of sample used and the composition of the samples.

Table 1: Formulations used for determining PAT, ANC and ANP.

\begin{tabular}{|llll|}
\hline Formulation & $\mathrm{Mg}(\mathrm{OH})_{2}$ & $\mathrm{Al}(\mathrm{OH})_{2}$ & Others \\
\hline F1 & $250 \mathrm{mg}$ & $250 \mathrm{mg}$ & Dimethicone \\
\hline F2 & $100 \mathrm{mg}$ & $5000 \mathrm{mg}$ & Dimethicone \\
\hline F3 & - & - & Sodium alginate, sodium bicarbonate, calcium carbonate \\
\hline F4 & - & - & Aluminium magnesium, hydroxide magaldrate $400 \mathrm{mg}$ \\
\hline F5 digene liquid & $185 \mathrm{mg}$ & $830 \mathrm{mg}$ & Na carboxymethylcellulose, Simethicone \\
\hline F6 & - & - & Mentha piperata \\
\hline F7 digene tablet & $50 \mathrm{mg}$ & $300 \mathrm{mg}$ & - \\
\hline F8 & - & - & Papain, alpha amylase \\
\hline F9 & - & - & Ayurvedic extracts \\
\hline F10 & $250 \mathrm{mg}$ & $250 \mathrm{mg}$ & - \\
\hline F11 & - & - & Ayurvedic extracts \\
\hline F12 & - & - & Mentha piperata \\
\hline F13 digene fizz & - & - & Svarjiksara, nimbukamlam \\
\hline
\end{tabular}

\section{METHODS}

The antacids were procured from a local pharmacy in Mumbai, India, in the month of February 2019. The samples F5 (Digene liquid), F7 (Digene tablet) and F13 (Digene Fizz Quick Release) were taken directly from Abbott India Ltd. All the chemicals used were of analytical grade. $\mathrm{pH}$ meter used was of Lab India Solutions, India. The $\mathrm{pH}$ meter was standardized at $\mathrm{pH}$ 4.0 with standardizing buffer and checked for operation at $\mathrm{pH} 1$ with $0.1 \mathrm{~N} \mathrm{HCl}$. The experiments were conducted in the department of Animal Biotechnology and Biochemistry, Kelkar Education Trust's, Scientific Research Centre, Mulund, Mumbai.

\section{Preliminary antacid test}

\section{Dosage}

Liquid sample: A well-mixed amount of the antacid product equivalent to the minimum labelled dosage; (here
$10 \mathrm{ml}$ ), was taken into a $100 \mathrm{ml}$ beaker. The volume was made up to $40 \mathrm{ml}$ using distilled water and the flask was kept on magnetic stirrer at $300 \pm 30 \mathrm{rpm}$ for about one minute

Chewable and non-chewable tablet sample: Two tablets (minimum labelled dosage) were crushed and water was added to a volume of $40 \mathrm{ml}$ followed by stirring $300 \pm 30$ rpm for about one minute on the magnetic stirrer.

Effervescent sample (quick releases): Minimum labelled dose was added to a beaker with $10 \mathrm{~mL}$ of distilled water and the solution was stirred while allowing the reaction to subside. The volume was then made up to $40 \mathrm{ml}$ using Distilled water and the mixture was stirred at $300 \pm 30 \mathrm{rpm}$ for about one minute.

$10 \mathrm{ml}$ of $0.5 \mathrm{~N} \mathrm{HCl}$ was added to the test solution while stirring on magnetic stirrer at $300 \pm 30 \mathrm{rpm}$. The stirring was continued for 10 mins. After $10 \mathrm{~min}$ the $\mathrm{pH}$ was recorded using $\mathrm{pH}$ meter calibrated at 4.0. The $\mathrm{pH}$ was 
noted down. The samples were further processed for acid Neutralization potential and acid Neutralization capacity if the $\mathrm{pH}$ recorded was above 3. . $^{7}$

\section{Acid neutralization capacity}

\section{Dosage}

Liquid sample: A well mixed amount of the antacid product equivalent to the minimum labelled dosage; here $10 \mathrm{ml}$, was taken into a $100 \mathrm{ml}$. beaker. The volume was made up to $70 \mathrm{ml}$ using distilled water and the flask was kept on magnetic stirrer at $300 \pm 30 \mathrm{rpm}$ for about one minute

Chewable and non-chewable tablet sample: Not less than 20 tablets were crushed and water was added to a volume of $70 \mathrm{ml}$ followed by stirring $300 \pm 30 \mathrm{rpm}$ for about one minute on the magnetic stirrer. Sample equivalent to $10 \mathrm{~g}$ was used for ANC determination.

Effervescent sample (quick releases): Minimum labelled dose was added to a beaker with $10 \mathrm{ml}$ of distilled water and the solution was stirred while allowing the reaction to subside. The volume was then made up to $70 \mathrm{ml}$ using Distilled water and the mixture was stirred at $300 \pm 30 \mathrm{rpm}$ for about one minute.

To each of the test samples, $30 \mathrm{ml}$ of $1.0 \mathrm{~N} \mathrm{HCl}$ was added and the solution was stirred at $300 \pm 30 \mathrm{rpm}$ for $10 \mathrm{~min}$. This was then back titrated with $0.5 \mathrm{~N} \mathrm{NaOH}$ (standardised with KHPh-potassium hydrogen phthalate). Titration was completed within 5 min until pH of 3.5 was obtained. The acid Neutralization capacity was stated as $\mathrm{mEq}$ of acid neutralized by the given antacid solution.

Total $\mathrm{mEq}=(60.0 \mathrm{ml})($ normality of $\mathrm{HCl})-(\mathrm{ml}$ of $\mathrm{NaOH})$ $(\mathrm{N}$ of $\mathrm{NaOH})$

Upon standardization of $1.0 \mathrm{~N} \mathrm{HCl}$ and $0.5 \mathrm{~N} \mathrm{NaOH}$, the normality was calculated and it was found to be $1.062 \mathrm{~N}$ for $\mathrm{HCl}$ and $0.6 \mathrm{~N}$ for $\mathrm{NaOH}$. The calculated normality of $\mathrm{HCl}$ and $\mathrm{NaOH}$ was utilized to determine the $\mathrm{mEq}$ of test samples. The experiment was carried out in triplicates. ${ }^{8}$

\section{Acid neutralization potential}

\section{Dosage}

Liquid sample: A well-mixed amount of the antacid product equivalent to the minimum labelled dosage; here $10 \mathrm{ml}$, was taken into a $100 \mathrm{ml}$. beaker. The volume was made up to $30 \mathrm{ml}$ using distilled water and the flask was kept on magnetic stirrer at $300 \pm 30 \mathrm{rpm}$ for about one minute

Chewable and non-chewable tablet sample: Not less than 20 tablets were crushed and water was added to a volume of $70 \mathrm{ml}$ followed by stirring $300 \pm 30 \mathrm{rpm}$ for about one minute on the magnetic stirrer. Sample equivalent to $10 \mathrm{~g}$ was used for ANP determination.

Effervescent sample (quick releases): Minimum labelled dose was added to a beaker with $10 \mathrm{ml}$ of distilled water and the solution was stirred while allowing the reaction to subside. The volume was then made up to $30 \mathrm{ml}$ using distilled water and the mixture was stirred at $300 \pm 30 \mathrm{rpm}$ for about one minute.

The acid reactivity of the antacid tablets was determined by a modified procedure of Rosette and Rice. ${ }^{9} 70 \mathrm{ml}$ of $0.1 \mathrm{~N} \mathrm{HCl}$ was added to the test samples and the contents of the beaker were stirred by the means of a magnetic stirrer at $300 \pm 30 \mathrm{rpm}$ for $10 \mathrm{~min}$. The $\mathrm{pH}$ meter and a pump calibrated to deliver $0.1 \mathrm{~N} \mathrm{HCl}$ at a constant rate of $2.0 \mathrm{ml} / \mathrm{min}$ were activated. The $\mathrm{pH}$-time profile was recorded throughout the test. The test was conducted until the $\mathrm{pH}$ of the reaction mixture fell below 3.0. The test was performed in duplicates. For five formulations F1, F5, F7, F9, F10 and F13, the onset of action in seconds was also recorded to choose best formulation capable of imparting better antacid potential. For rapid onset of reaction, the samples were prepared as mentioned in ANP. $0.1 \mathrm{~N} \mathrm{HCl}$ was kept on the magnetic stirrer with $\mathrm{pH}$ electrode and to this the prepared antacid solution was added. Time taken for increasing $\mathrm{pH}$ above 3.5 was recorded.

\section{RESULTS}

\section{PAT}

PAT is used to classify the formulations as potent antacids. Out of the 12 formulations, F6 and F12 showed $\mathrm{pH}$ as low as 1.17 and 1.07 respectively. These two formulations will not be considered as potent antacids according to US pharmacopoeia definition of classifying and defining formulations as antacids. These two formulations were also not considered for calculating ANC and ANP. The pH of other samples was significant (3-5) to consider the formulations as antacids. Of all the tested samples, F2 (4.10), F5 (4.07), F7 (3.83), F8 (4.36) showed $\mathrm{pH}$ between 3 and 5 . However, other antacid formulations showed significantly higher $\mathrm{pH}$ values such as F1 (6.29), F3 (5.93), F4 (4.99), F9 (6.01), F10 (5.87), F11 (5.87), and F13 (5.86). According to the literature, the antacid formulations should have $\mathrm{pH}$ between 3 and 5 (Table 2).

\section{$A N C$}

Volume of $\mathrm{NaOH}$ added to bring the $\mathrm{pH}$ above 3.5 dictates the amount of unutilized $\mathrm{HCl}$ that remains in the antacid-acid solution. More the volume of $\mathrm{NaOH}$ required to neutralize acid, lesser is the ANC of the sample. According to Table 3, least amount of $\mathrm{NaOH}$ was added to F5 (37.2) and highest number of moles required to neutralize unutilized $\mathrm{HCl}$ was for sample $\mathrm{F} 3$. The ANC of F5 was found to be highest as $41.5 \mathrm{mEq}$ amongst all the 
tested samples. The liquid samples $(10 \mathrm{ml})$ showed higher ANC as compared to tablets (20 g). F7 showed an ANC of 26.22 which was highest among all the antacid tablets tested for ANC. From the composition of the antacid tablets and tests performed it was conclusive that formulations with higher $\mathrm{Al}(\mathrm{OH})_{2}$ concentration performed better as acid neutralizers as compared to antacids with lower composition of $\mathrm{Al}(\mathrm{OH})_{2}$ even when $\mathrm{pH}$ was high for latter case for samples such as F1, F3, F9, F10 and F13. But extremely high amount (F2) of $\mathrm{Al}(\mathrm{OH})_{2}$ had no effect on ANC. Thus, there might be no correlation between preliminary antacid ability and ANC of an antacid formulation.

ANC of the antacids was calculated by:

Moles of $\mathrm{HCl}$ added = volume of $\mathrm{HCl} \times$ normality of $\mathrm{HCl}$

Therefore, moles of $\mathrm{HCl}$ added $=60 \times 1.062=63.72$ moles.
ANC $(\mathrm{mEq})=$ moles of $\mathrm{HCl}$ added-moles of $\mathrm{NaOH}$ required for neutralization.

Table 2: PAT of 13 marketed products.

\begin{tabular}{|ll|}
\hline Sample & PAT \\
\hline F1 & $6.29 \pm 0.21$ \\
\hline F2 & $4.10 \pm 0.12$ \\
\hline F3 & $5.53 \pm 0.18$ \\
\hline F4 & $4.98 \pm 1.2$ \\
\hline F5 & $4.07 \pm 0.45$ \\
\hline F6 & $1.17 \pm 0.67$ \\
\hline F7 & $3.83 \pm 0.17$ \\
\hline F8 & $4.36 \pm 0.18$ \\
\hline F9 & $6.01 \pm 0.87$ \\
\hline F10 & $5.87 \pm 0.88$ \\
\hline F11 & $5.87 \pm 0.17$ \\
\hline F12 & $1.07 \pm 0.14$ \\
\hline F13 & $5.86 \pm 0.31$ \\
\hline All data are shown as the means \pm SD for triplicate. \\
\hline
\end{tabular}

Table 3: ANC of 13 marketed products.

\begin{tabular}{|llllll|}
\hline Sample & Sample volume & Average & Standard deviation & Moles of NaOH required & ANC \\
\hline F1 & $10 \mathrm{ml}$ & 49.9 & 0.17 & 29.94 & 33.78 \\
\hline F2 & $10 \mathrm{ml}$ & 53.1 & 0.36 & 31.86 & 31.86 \\
\hline F3 & $10 \mathrm{ml}$ & 85.5 & 0.23 & 31.34 & 12.38 \\
\hline F4 & $10 \mathrm{ml}$ & 65.0 & 0.11 & 22.22 & 24.68 \\
\hline F5 & $10 \mathrm{ml}$ & 37.0 & 0.15 & - & 41.5 \\
\hline F6 & NA & - & - & 37.5 & - \\
\hline F7 & 20 tablets & 62.8 & 0.28 & 50.98 & 26.22 \\
\hline F8 & One packet & 84.9 & 0.05 & 36.66 & 12.74 \\
\hline F9 & One packet & & 0.05 & 45.32 & 27.06 \\
\hline F10 & 20 tablets & 75.5 & 0.25 & - & 18.4 \\
\hline F11 & One packet & 62.5 & 0.50 & 33.5 & 26.22 \\
\hline F12 & NA & - & - & - \\
\hline F13 & One packet & 51 & 0.86 & 29 \\
\hline All
\end{tabular}

All data are shown as the means \pm SD for triplicate.

Table 4: ANP of 13 marketed products.

\begin{tabular}{|c|c|c|c|c|c|c|}
\hline \multirow[b]{2}{*}{ Sample } & \multirow[b]{2}{*}{ Initial pH } & \multirow{2}{*}{$\begin{array}{l}\text { Onset of reaction } \\
\text { (second) }\end{array}$} & \multicolumn{3}{|l|}{ Time taken } & \multirow[t]{2}{*}{ Final pH } \\
\hline & & & $\begin{array}{l}\text { To reach above } \\
\text { pH } 3.5 \text { (in min) }\end{array}$ & $\begin{array}{l}\text { To reach max } \\
\text { pH (in min) }\end{array}$ & $\begin{array}{l}\text { To maintain pH above } \\
3.5 \text { (in min) ANP }\end{array}$ & \\
\hline F1 & 1.85 & 128 & 0 & 12 & 71 & 2.87 \\
\hline F2 & 1.70 & - & 1.5 & 7 & 60 & 2.78 \\
\hline F3 & 3.85 & - & 0 & 1 & 70 & 1.87 \\
\hline F4 & 2.3 & - & 1 & 1 & 39 & 2.97 \\
\hline F5 & 3.05 & 28 & 0 & 0.5 & 68 & 2.93 \\
\hline F6 & - & - & - & - & - & - \\
\hline F7 & 3.87 & $>300$ & 0 & 1 & 54 & 2.35 \\
\hline F8 & 4.10 & - & 0 & 2 & 72 & 2.83 \\
\hline F9 & 5.67 & 2 & 0 & 2 & 90 & 2.81 \\
\hline F10 & 4.95 & 46 & 0 & 3 & 53 & \\
\hline F11 & 5.10 & - & 0 & 1 & 87.5 & 2.5 \\
\hline F12 & - & - & - & - & - & - \\
\hline F13 & 4.72 & 2 & 0 & 3 & 100 & 2.78 \\
\hline
\end{tabular}




\section{ANP}

All the samples could bring $\mathrm{pH}$ above 3.5 and maintain it for about 50-100 min. Samples were added to $\mathrm{HCl}$ and allowed to stand for $10 \mathrm{~min}$ after which ANP was calculated. For all the samples $\mathrm{pH}$ recorded after this was above 3.5 except for sample F2 and F4 which took additional 1.5 and 1 minutes respectively to bring $\mathrm{pH}$ above 3.5 Formulations F2 and F4 thus were not considered for measuring rapid onset of reaction. F6 and F12 were not considered for ANC and ANP as well because PAT results yielded $\mathrm{pH}$ below 3. F3 and F10 showed low ANC and hence were not considered for rapid onset of reaction. Remaining six samples F1, F5, F7, F9, F10 and F13 were checked for onset of action. Formulation F9 and F13 could raise the $\mathrm{pH}$ above 3.5 within 2 seconds, followed by sample F5, F10 and F1 which took 28, 46 and 128 seconds respectively. Sample F7, however took more than 300 seconds to bring $\mathrm{pH}$ above 3.5 (Table 4).

\section{DISCUSSION}

Many parameters such as cost, acid neutralizing capacity and potential of the antacid formulations play crucial role in selection of OTC antacids. ${ }^{10}$ Under in vitro conditions, 13 marketed products were studied for PAT, ANC and ANP. The antacids with higher $\mathrm{pH}$ did not show relevance in terms of ANC suggesting no correlation might exist between the two parameters. Formulations showing higher ANC will also have higher symptomatic relief against hyperacidity. Antacids showing moderate to low ANC can be re-studied by increasing the volume more than minimum labelled dosage. According to Jakaria et al, sodium alginate and sodium bi-carbonate containing antacids gave highest ANC. ${ }^{7}$ However in the current study, formulations with Na- Alginate ( $\mathrm{pH}$ 5.53) and alpha-amylase showed least ANC. Antacid Formulations with sodium bicarbonate, calcium carbonate, and ayurvedic plant extracts showed moderated ANC. Antacids with aluminium hydroxide and magnesium hydroxide showed extremely high ANC. Katakam et al have reported highest ANC by magnesium and aluminium hydroxide containing antacids. ${ }^{10}$ In addition to highest ANC, aluminium hydroxide-containing antacids are also known to prevent grossly visible mucosal necrosis and hemorrhages in stomach produced by noxious agents, such as aspirin or absolute ethanol. ${ }^{11}$ Quick release F13 showed highest ANP; however, the duration till the 13 antacids could maintain $\mathrm{pH}$ above 3.5 were mostly comparable. A buffering $\mathrm{pH}$ was not observed for quick releases. Onset of action, another important parameter for studying rapidness of antacid formulation was measure for high ANC formulations and turns out that onset was highest for formulations F5 (28 seconds) and F9 and F13 (less than 2 seconds). Differences observed between the antacid formulations may be attributed to different reactivity of the raw materials used in the products, or formulation and processing variables.

\section{CONCLUSION}

Antacids with aluminium hydroxide and magnesium hydroxide showed better antacid properties and fast relief followed by sodium bicarbonate, calcium carbonate, and ayurvedic plant extracts. Antacids with Na- Alginate and alpha-amylase showed very low ANC. These findings indicate the need for determination of proper dosage of the antacid formulations without plausible side effects. The data would aid in providing insights into the development of design and discovery of new antacid formulations.

\section{ACKNOWLEDGEMENTS}

The authors would extend appreciation to Abbott India Ltd, India for funding the project.

\section{Funding: Abbott India Ltd \\ Conflict of interest: None declared \\ Ethical approval: Not required}

\section{REFERENCES}

1. Martinsen TC, Bergh K, Waldum HL. Gastric juice: a barrier against infectious diseases. Basic Clin Pharmacol Toxicol. 2005;96(2):94-102.

2. Maity P, Biswas K, Chattopadhyay I, Banerjee RK, Bandyopadhyay $\mathrm{U}$. The use of neem for controlling gastric hyperacidity and ulcer. Phytother Res. 2009;23(6):747-55.

3. Díaz-Rubio M. Historical perspective of gastric acid inhibition. Drugs. 2005;65(1):1-6.

4. Nahar N, Choudhuri MS, Alamgir M. Preliminary in vitro evaluation of some traditional Ayurvedic antacids. Oriental Pharma Experimental Med. 2007;7(4):441-3.

5. Jakaria M, Zaman R, Parvez M, Islam M, Haque MA, Sayeed MA, et al. Comparative study among the different formulation of antacid tablets by using acidbase neutralization reaction. Global J Pharmacol. 2015;9(3):278-81.

6. Miederer SE, Wirtz M, Fladung B. Acid neutralization and bile acid binding capacity of hydrotalcite compared with other antacids: An in vitro study. Chinese J Digest Dis. 2003;4(3):140-6.

7. Hirani JJ, Rathod DA, Vadalia KR. Orally disintegrating tablets: a review. Trop J Pharm Res. 2009;8(2):161-72.

8. Spivey RJ, Goodhart FW. In vitro acid reactivity of three commercial antacid tablets. Am J Hospital Pharm. 1979;36(5):660-3.

9. Rosset NF, Rice ML Jr. An in vitro evaluation of the efficacy of the more frequently used antacids with particular attention to tablets. Gastroenterology. 1954;26(3):490-5

10. Katakam P, Rajab J. A Comparative Study of the Acid Neutralizing Capacity of Various Commercially Available Antacid Formulations in Libya. Libyan $\mathbf{J}$ Med Res. 2010;7(1):41-9. 
11. Domschke W, Hagel J, Ruppin H, Kaduk B. Antacids and gastric mucosal protection. Scandinavian $\mathrm{J}$ Gastroenterol. 1986;21(125):144-50.
Cite this article as: Dhawal PP, Barve SS. Preliminary in-vitro evaluation of marketed formulations for antacid activity. Int J Basic Clin Pharmacol 2020;9:57-62. 